\title{
The severity and risk factors for mortality in immunocompromised adult patients hospitalized with influenza-related pneumonia
}

Liang Chen ( $\square$ chenliang1995@sina.com )

Beijing Jishuitan Hospital

\section{Xiudi Han}

Qingdao Municipal Hospital Group

YanLi Li

Beijing Chao-Yang Hospital: Beijing Chaoyang Hospital

Chunxiao Zhang

Beijing Huimin Hospital

Xiqian Xing

The 2nd People's Hospital of Yunnan Province

\section{Research}

Keywords: Immunocompromised, Influenza-related pneumonia, Severity, risk factor, Mortality

Posted Date: February 25th, 2021

DOI: https://doi.org/10.21203/rs.3.rs-238430/v1

License: (c) (1) This work is licensed under a Creative Commons Attribution 4.0 International License. Read Full License 


\section{Abstract}

Objective To explore disease severity and risk factors for 30-day mortality of adult immunocompromised (IC) patients hospitalized with influenza-related pneumonia (Flu-p).

Method A total of 122 IC and 1,191 immunocompetent patients hospitalized with Flu-p from January 2012 to December 2018 were recruited retrospectively from five teaching hospitals in China.

Results After controlling for confounders, multivariate logistic regression analysis showed that immunosuppression was associated with increased risks for invasive ventilation [odds ratio: $(O R) 2.475$, 95\% confidence interval (C): 1.511-4.053, $\mathrm{p}<0.001$ ], admittance to the intensive care unit (OR:3.247, 95\% Cl: 2.064-5.106, $\mathrm{p}<0.001)$, and 30-day mortality (OR: 3.206, 95\% Cl: $1.926-5.335, \mathrm{p}<0.001)$ in patients with Flu-p. Another multivariate logistic regression model revealed that baseline lymphocyte counts (OR: 0.993, 95\% Cl: 0.990-0.996, p < 0.001), coinfection (OR: 5.450, 95\% C:I1.638-18.167, p = 0.006), early neuraminidase inhibitor therapy $(O R 0.401,95 \% \mathrm{Cl} 0.127-0.878, \mathrm{p}=0.001)$, and systemic corticosteroid use at admission (OR: 6.414, 95\% C:/1.348-30.512, $\mathrm{p}=0.020)$ were independently related to 30-day mortality in IC patients with Flu-p. Based on receiver operating characteristic curve (ROC) analysis, the optimal cutoff for lymphocyte counts was $0.6 \times 10^{9} / \mathrm{L}$ [area under the ROC $(A U R O C)=0.824,95 \% \mathrm{Cl}: 0.744$ - 0.887], sensitivity: $97.8 \%$, specificity: $73.7 \%]$.

Conclusions IC conditions are associated with more severe outcomes in patients with Flu-p. The predictors for mortality that we identified may be valuable for the management of Flu-p among IC patients.

\section{Introduction}

Influenza is a common viral respiratory disease that affects between $5 \%$ and $10 \%$ of the world's population each year, resulting in roughly 3-5 million severe infections and 290,000 - 650,000 annual deaths [1-2]. Influenza-related pneumonia (Flu-p) is a severe form of influenza infection associated with over $50 \%$ of influenza-related hospitalizations [3-4].

In recent years, immunocompromised (IC) status has become increasingly recognized as frequent comorbidity of influenza [5]. Observational studies have shown that the influenza vaccine is less effective in IC populations [6-7]. Together with decreased host defenses, IC individuals have increased susceptibility to influenza virus infection, and have a greater risk of severe outcomes [8-9]. However, most previous researchers have only focused on patients with specific subtypes of IC conditions [e.g., stem cell transplantation, human immunodeficiency virus /acquired immune deficiency syndrome (HIV/AIDS)], which limits the generalizability of the conclusions [5,8-10]. Data on patients with influenza-related pneumonia (Flu-p) is particularly scarce. Additionally, prognostic factors among IC patients with influenza remain largely unknown. 


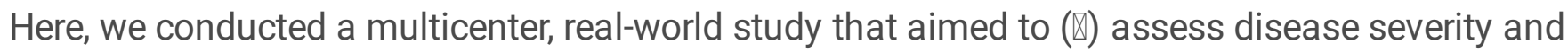
outcomes of IC adult patients hospitalized with community-onset Flu-p, and ( $\mathbb{Z})$ to explore the baseline predictors for mortality in these patients.

\section{Methods}

\section{Patient recruitment}

Patients who had been tested for the influenza virus at five tertiary hospitals in China between January $1^{\text {st }}, 2012$ and December $31^{\text {st }}, 2018$ (Supplementary Material 1) were screened for eligibility. Patients with confirmed Flu-p were enrolled in this study. Patients were excluded if they: (i) were not classified as having community-onset pneumonia (i.e., were hospitalized within the last 28 days, with pneumonia onset $\geq 48 \mathrm{~h}$ after admission [11]), as the inclusion of non-community-onset pneumonia cases could have complicated result interpretation; and (ii) were $<14$ years old.

\section{Study definitions}

Patients with Flu-p were defined as individuals for whom polymerase chain reaction (PCR) analyses of respiratory specimens (including sputum, nasal/nasopharyngeal swabs, bronchial aspirates, and bronchoalveolar lavage fluid) were positive for influenza viral RNA, and for whom respiratory symptoms and chest radiographic findings were consistent with newly emergent chest infiltrates. IC patients included primary immune deficiency diseases, active malignancy, HIV infection with a CD4 T-lymphocyte count $<200$ cells $/ \mathrm{mL}$ or percentage $<14 \%$, immunosuppressive therapy (Supplementary Material 2 ), solid organ transplantation, hematopoietic stem cell transplantation, splenectomy [12]. Patients who had early neuraminidase inhibitor (NAI) therapy were those who had been administered NAl agents within two days of symptom onset [13]. Patients who had systemic corticosteroid treatment were those who had been administered one or more systemic corticosteroid doses at the day of admission. Patients with community-acquired co-infecting respiratory pathogens were those who had pathogens detected via standard microbiological techniques (Supplementary Material 3) within $48 \mathrm{~h}$ of admission [14].

\section{Data Collection}

Data were extracted from patient medical records with standardized case report forms, and included demographic details, comorbidities (see Supplementary Material 2), baseline symptoms, vital signs, laboratory results, radiographic findings, community-acquired co-infecting respiratory pathogens, patient management, and outcome data [including NAl use, antibiotic use, systemic corticosteroid administration, noninvasive/invasive ventilation, admittance to the intensive care unit (ICU), complications during hospitalization and 30-day mortality]. Outcomes for those hospitalized for $<30$ days were established through telephone follow-up.

\section{Statistical analysis}


A Kolmogorov-Smirnov test was used to assess result normality, with normally and non-normally distributed variables presented as means \pm standard deviation $( \pm S D)$ and medians, respectively. Continuous variables were evaluated with Mann-Whitney $U$ tests or Student's t-tests, whereas categorical variables were assessed with Fisher's exact test or chi-squared tests. A two-tailed $P<0.05$ indicated statistical significance. SPSS 22.0 or MedCalc 19.0 were used for all statistical tests.

To evaluate the effects of IC status on clinical outcomes, we performed multivariate backward stepwise logistic regression after adjusting for age, sex, duration from illness onset to hospital admission, influenza virus type, comorbidities, pregnancy, obesity, smoking history, receipt of early NAl therapy, systemic corticosteroid use and coinfection with other pathogens. Those risk factors had previously been associated with clinical outcomes in patients with influenza [15].

IC Flu-p patients were divided into surviving and deceased groups according to survival status at 30 days post-admission, and baseline characteristics were compared between the two groups. To explore the risk factors for 30-day mortality in IC, Flu-p patients, variables with $p$-values $<0.1$ in univariate analyses were entered into the multivariate backward stepwise logistic regression analysis. The optimal cut-off and predictive value of lymphocyte counts were assessed using the area under the receiver characteristics curve (AUROC) based upon Youden's index.

\section{Results}

\section{Screening Process}

A total of 3405 hospitalized patients with RNA tests positive for influenza and 1313 eligible adult patients with Flu-p were included in the final analysis, including 1191 immunocompetent patients and $122 \mathrm{IC}$ patients (Fig.1). The three most common immunocompromising conditions were immunosuppressive therapy $(57 / 122,46.7 \%)$, active malignancy $(25 / 122,20.5 \%)$ and organ transplantation $(17 / 122,13.9 \%)$ (Supplementary Material 4).

\section{Comparison of clinical characteristics and outcomes between IC and non-IC patients with Flu-p}

Compared with non-IC patients, IC patients were younger (median: 45.0 years vs. 61.0 years, $p<0.001$ ), and were admitted to hospitals earlier after illness onset (median: 2.0 days vs. 4.0 days, $p<0.001$ ). Chest pain $(31.1 \%$ vs. $17.2 \%, \mathrm{p}<0.001)$ and pleural effusion $(47.5 \%$ vs. $32.0 \%, \mathrm{p}<0.001)$ at admission were present significantly more often in IC patients, while fever $(63.9 \%$ vs. $76.6 \%, p<0.001)$ was present significantly less often. Baseline lymphocyte counts were significantly lower in IC patients than in non-IC patients [ $(0.9 \pm 0.6) v s .(1.2 \pm 0.8), p<0.001]$. Other baseline vital signs, symptoms, and laboratory and radiologic findings were similar between patients in the two groups (Table 1 ).

Compared to non-IC patients, IC patients $(43.4 \%$ vs. $34.0 \%, \mathrm{p}=0.037)$ were more commonly coinfected with other pathogens at admission. Incidence of gram-negative bacterium (69.8\% vs. $48.4 \%, p=0.003)$, fungus $(11.3 \%$ vs. $0.5 \%, \mathrm{p}<0.001)$ and Cytomegalovirus (CMV) $(3.8 \%$ vs. $0.0 \%, \mathrm{p}<0.001)$ was higher in 
IC patients, while the proportion of gram-positive bacterium $(37.7 \% v s .55 .1 \%, p=0.017)$ was lower (Supplementary Material 5).

All of the Flu-p patients were administered antibiotics during their hospital stays. Compared to non-IC patients, less IC patients were administrated with systemic corticosteroids at admission $(7.1 \%$ vs $26.2 \%, \mathrm{p}$ $<0.001)$; more IC patients received noninvasive ( $48.8 \%$ vs. $25.7 \%, \mathrm{p}<0.001)$ and invasive $(30.3 \%$ vs. $17.7 \%, \mathrm{p}=0.001)$ ventilation. Additionally, respiratory failure $(41.0 \%$ vs. $22.9 \%, \mathrm{p}<0.001)$, heart failure (34.4\% vs. $23.9 \%, \mathrm{p}=0.011)$, nosocomial pneumonia ( $17.2 \%$ vs. $7.4 \%, \mathrm{p}<0.001)$, septic shock $(19.7 \%$ vs. $8.0 \%, \mathrm{p}<0.001)$ and nosocomial blood stream infections $(7.4 \% v s .0 .8 \%, \mathrm{p}<0.001)$ were more frequent in IC patients. The duration between admission to clinical stability (median: 14.0 days vs. 3.0 days, $p<$ 0.001 ), as well as the length of hospital stays (median: 17.0 days $v s .10 .0$ days, $p<0.001$ ) were significantly longer for IC patients than for non-IC patients. Finally, more IC patients were admitted to the ICU $(48.4 \%$ vs. $22.4 \%, \mathrm{p}<0.001)$, and the all-cause 30 -day mortality rate $(37.7 \%$ vs. $20.3 \%, \mathrm{p}<0.001)$ was higher in IC patients (Table 2).

\section{Impact of immunocompromised status on clinical outcomes for Flu-p patients}

After controlling for age, sex, duration between illness onset and admission, influenza virus type, comorbidities, pregnancy, obesity, smoking history, early NAl therapy, administration of systemic corticosteroids, antibiotics use, and coinfection with other community-acquired pathogens, IC status was associated with increased risks for invasive ventilation [odds ratio $(O R): 2.475,95 \%$ confidence interval (IC): 1.511-4.053, p < 0.001] , ICU admission (O:R3.247, 95\% Cl: 2.064-5.106, p < 0.001) and 30-day mortality (OR:3.206, 95\% Cl: 1.926-5.335, $\mathrm{p}<0.001)$ for patients with Flu-p (Table 2).

\section{Baseline predictors for 30-day mortality in IC patients with Flu-p}

Results from univariate analysis revealed that respiratory rates $\geq 30$ breaths/min at admission, and decreased baseline blood lymphocytes, blood albumin, and $\mathrm{PaO}_{2} / \mathrm{FiO}_{2}$ were associated with an increased risk for 30-day mortality in IC patients with Flu-p (Supplementary Material 6).

A multivariate backward stepwise logistic regression suggested that lymphocyte counts (OR: 0.993, 95\% Cl: $0.990-0.996, \mathrm{p}<0.001)$, coinfection (OR: $5.450,95 \% \mathrm{Cl}: 1.638-18.167, \mathrm{p}=0.006)$, early NAl therapy (OR: 0.401, 95\% Cl: 0.127-0.878, $\mathrm{p}=0.001$ ), and systemic corticosteroid use at admission (OR: 6.414, 95\% $C l: 1.348-30.512, p=0.020$ ) were independent predictors for 30-day mortality in IC patients with Flu-p (Table 3).

\section{Association of coinfected pathogens with baseline lymphocytes and 30-day mortality in IC patients with Flu-p}

The baseline lymphocyte count levels for IC patients coinfected with gram-positive bacterium [(1.2 \pm 0.8$)$ $\left.\times 10^{9} / \mathrm{L}\right]$ was significantly higher than those for IC patients coinfected with gram-negative bacterium [ $(0.5$ $\left.\pm 0.3) \times 10^{9} / \mathrm{L}, \mathrm{p}<0.001\right]$, gram-negative bacterium/fungus or CMV $\left[(0.3 \pm 0.2) \times 10^{9} / \mathrm{L}, \mathrm{p}<0.001\right]$ (Fig. $2 \mathrm{~A}$ ). 
The survival rates of IC patients coinfected with gram-negative bacterium $(80.0 \%$ vs. $25.0 \%, p<0.001)$ and gram-negative bacterium/fungus or CMV (83.3\% vs. 25.0\%, p < 0.001) were lower than those of IC patients coinfected with gram-positive bacterium (25.0\%) during the first 30 days after admission (Fig. 2B).

\section{Baseline lymphocytes as predictors for 30-day mortality in IC patients with Flu-p}

The ROC determined that the optimal cutoff of baseline lymphocyte counts was $0.6 \times 10^{9} / \mathrm{L}$, which reached an AUROC of 0.825 (95\% Cl: $0.744-0.887$ ), with sensitivity of $97.8 \%$ and specificity of $73.7 \%$ (Fig. 3A).

The Kaplan-Meier curves showed that the 30-day mortality of IC patients with baseline lymphocyte counts $\leq 0.6 \times 10^{9} / \mathrm{L}$ was higher than that of patients with lymphocyte counts $>0.6 \times 10^{9} / \mathrm{L}(69.2 \% \mathrm{Vs}$. $1.8 \%$, log-rank test, $p<0.001$ ) (Fig. 3B).

\section{Discussion}

In this multicenter study, we found that IC status correlated with worse clinical outcomes in patients hospitalized with Flu-p. Additionally, we identified several early predictors of mortality for IC patients with Flu-p, which may help inform treatment regimens.

In our cohort, IC patients accounted for $9.3 \%$ of all Flu-p patients, which was consistent with previous reports of 5-15\% IC incidence in severe influenza [5-10]. Compared to non-IC patients with Flu-p, we found that IC patients tended to be younger, presented with chest pain and pleural effusion more often, presented with fevers less frequently, and had lower level of blood lymphocytes. The other baseline clinical features were similar. Memoli and colleagues [16] reported that IC patients with influenza demonstrated fewer clinical symptoms and signs on clinical assessment. However, Collins et al [17] showed that some symptoms and signs (e.g., fever, sore throat, myalgias, and headaches) were more common in IC patients with influenza. One possible explanation was for this difference is the discrepancy in evaluation timing. As influenza is a potentially progressive disease, some clinical features might be latent early in the disease course [18]. Another potential cause is that prior use of systemic corticosteroids and immunosuppressants might conceal symptoms in IC patients with influenza [19-20].

Although similar baseline clinical characteristics were observed between the patients with and without immunocompromising conditions, disease severity in IC patients was greater than that in immunocompetent patients. IC adults were more likely to experience worse outcomes, including longer hospital stays, more complications, increased risks for intubation, and increased risk for ICU admission and death, all of which were in line with most previous reports [5-10,16-17]. However, we used a more broad definition of immunocompromised status, which means our results have more general significance. 
We also identified risk factors that were predictors for death in IC patients with Flu-p, many of which have also been related to outcomes among immunocompetent influenza patients in previous research. Severe influenza is characterized by lymphocytopenia in $30-100 \%$ of cases [21-22], although the mechanistic basis for this finding remains poorly understood. There is some evidence that CD4+ and CD8+ T cells may undergo higher rates of apoptotic death in individuals with severe disease, owing to higher circulating levels of soluble Fas ligand and caspase-1 [23], and thereby contributing to an overall decline in lymphocyte counts. Such virus-induced lymphocytopenia can delay viral clearance. Alternatively, these lymphocytes may be recruited to the respiratory tract and other organs, resulting in their apparent depletion from circulation [24]. Lymphocyte accumulation within the lungs can drive severe localized inflammation and tissue damage. Previous studies reported that the predictive value of baseline blood lymphocyte counts was $0.8 \times 10^{9} / \mathrm{L}$ in immunocompetent patients with severe influenza [25-26]. However, because individuals with compromised factors often have low lymphocyte counts before coming down with influenza [27-28], it is reasonable to expect that the optimal cutoff could differ. Su-Mi Choi et al. reported that, in hematopoietic cell transplant recipients with influenza, profound lymphopenia (< $300 \times 10^{9} / \mathrm{L}$ ) was a significant risk factor for death [29]. In HIV/ARDS individuals with A (H1N1) infection, patients with CD4 T-cell count $<200 \times 10^{9} / \mathrm{L}$ experienced worse outcomes [30]. Our study suggested that, in general, in IC patients with Flu-p, baseline lymphocyte counts of $0.6 \times 10^{9} / \mathrm{L}$ could be used as an independent prognostic factor.

Coinfection has previously been shown to be related to adverse outcomes in immunocompetent patients with severe influenza [31-32], as well as in IC individuals, highlighting the importance of timely infection control. Further, we found the survival rates of IC patients coinfected with gram-negative bacteria or fungus/CMV were significantly lower than those coinfected with gram-positive pathogens. Additionally, IC patients coinfected with gram-negative bacteria often had lower baseline blood lymphocyte counts. Thus, lymphopenia might be associated with increased mortality among Flu-p patients in multiple ways.

Previous observational studies have suggested that inhibiting viral replication at an early stage can reduce virus-induced inflammation and tissue damage, and thereby decrease overall influenza-related mortality rates for immunocompetent patients [33]. Our results showed it was still associated with better outcomes in IC patients with Flu-p. Early inhibition of viral replication might be particularly crucial in IC patients with influenza, because prolonged viral shedding is associated with the emergence of drugresistant viruses and more severe disease courses [34-35]. Meanwhile, systemic corticosteroids use may cause increased death by extensive suppression of humoral and cellular immunity [36], even in patients with immunocompromised factors.

Our study design has some limitations. First, as it was retrospective in nature, it was susceptible to selection bias. For example, nucleic acid tests for influenza were conducted based upon the subjective judgment of attending physicians. Thus, it is possible that only patients with more severe disease manifestations may have undergone testing, rather than all potentially eligible patients. Second, the sample of IC patients was relatively small. Third, because of the retrospective study design, we were 
unable to retrieve and evaluate vaccination data or other missing information, potentially constraining the accuracy of our results.

Despite these limitations, however, our study showed that IC status has a consistent and wide-ranging negative impact on clinical outcomes among patients hospitalized with Flu-p. The risk factors for mortality identified in our study may be helpful for clinicians who manage IC patients with Flu-p.

\section{Abbreviations}

Flu: influenza; Flu-p: influenza-related pneumonia ; IC: immunocompromised; ICU: intensive care unit; NAl: neuraminidase inhibitor; HIV/ARDS: human immunodeficiency virus/acquired immune deficiency syndrome; OR: odd ratio; 95\% Cl: 95\% confidence interval; AUROC: under the receiver-operating characteristic curve; ICU: intensive care unit.

\section{Declarations}

\section{Ethics approval and consent to participate}

The study design was approved by the Ethics Committee of Beijing Jishuitan Hospital (No.201911-15). Given the retrospective nature of the study, the Ethics Committee determined that an informed consent was not necessary.

\section{Consent for publication}

Not applicable

\section{Availability of data and materials}

The datasets used and/or analysed during the current study are available from the corresponding author on reasonable request.

\section{Competing interests}

The authors declare that they have no competing interests.

\section{Funding}

This study was founded by Beijing JST research (ZR-201921). The sponsor had no role in study design;the collection, analysis and interpretation of data; the writing of the report; and the decision to submit the article for publication.

\section{Authors' contributions}


Study concept and design: LC, XdH. Acquisition of data: LC, XdH, YIL, CXZ, XqX. Statistical analysis of data: LC. Drafting of the manuscript: LC. Critical revision of the manuscript for important intellectual content: $\mathrm{XdH}, \mathrm{XqX}$. All authors agree with the article submission. All authors read and approved the final manuscript.

\section{Acknowledgements}

The authors would like to express their gratitude to MedEdit LLI for the expert linguistic services provided.

\section{References}

1. Webster RG, Govorkova EA: Continuing challenges in influenza. Ann N Y Acad Sci 2014, 1323:115139.

2. Uyeki TM: Influenza. Ann Intern Med 2017, 167(5):ITC33-ITC48.

3. Jain S, Kamimoto L, Bramley AM, Schmitz AM, Benoit SR, Louie J, Sugerman DE, Druckenmiller JK, Ritger KA, Chugh R et al: Hospitalized patients with 2009 H1N1 influenza in the United States, AprilJune 2009. N Engl J Med 2009, 361(20):1935-1944.

4. Chen L, Han X, Bai L, Zhang J: Clinical characteristics and outcomes in adult patients hospitalized with influenza, respiratory syncytial virus and human metapneumovirus infections. Expert Rev Anti Infect Ther 2020:1-10.

5. Lapinsky SE: H1N1 novel influenza A in pregnant and immunocompromised patients. Crit Care Med 2010, 38(4 Suppl):e52-57.

6. Samson SI, Leventhal PS, Salamand C, Meng Y, Seet BT, Landolfi V, Greenberg D, Hollingsworth R: Immunogenicity of high-dose trivalent inactivated influenza vaccine: a systematic review and metaanalysis. Expert Rev Vaccines 2019, 18(3):295-308.

7. Hughes K, Middleton DB, Nowalk MP, Balasubramani GK, Martin ET, Gaglani M, Talbot HK, Patel MM, Ferdinands JM, Zimmerman RK et al: Effectiveness of Influenza Vaccine for Preventing LaboratoryConfirmed Influenza Hospitalizations in Immunocompromised Adults. Clin Infect Dis 2021.

8. Lin JC, Nichol KL: Excess mortality due to pneumonia or influenza during influenza seasons among persons with acquired immunodeficiency syndrome. Arch Intern Med 2001, 161(3):441-446. .

9. Nichols WG, Guthrie KA, Corey L, Boeckh M: Influenza infections after hematopoietic stem cell transplantation: risk factors, mortality, and the effect of antiviral therapy. Clin Infect Dis 2004, 39(9):1300-1306.

10. Mombelli M, Kampouri E, Manuel O: Influenza in solid organ transplant recipients: epidemiology, management, and outcomes. Expert Rev Anti Infect Ther 2020, 18(2):103-112.

11. Chen L, Zhou F, Li H, Xing X, Han X, Wang Y, Zhang C, Suo L, Wang J, Yu G et al: Disease characteristics and management of hospitalised adolescents and adults with community-acquired pneumonia in China: a retrospective multicentre survey. BMJ Open 2018, 8(2):e018709. 
12. Ramirez JA, Musher DM, Evans SE, Dela Cruz C, Crothers KA, Hage CA, Aliberti S, Anzueto A, Arancibia F, Arnold F et al: Treatment of Community-Acquired Pneumonia in Immunocompromised Adults: A Consensus Statement Regarding Initial Strategies. Chest 2020, 158(5):1896-1911.

13. Katzen J, Kohn R, Houk JL, Ison MG: Early Oseltamivir After Hospital Admission Is Associated With Shortened Hospitalization: A 5-Year Analysis of Oseltamivir Timing and Clinical Outcomes. Clin Infect Dis 2019, 69(1):52-58.

14. Jain S, Self WH, Wunderink RG, Fakhran S, Balk R, Bramley AM, Reed C, Grijalva CG, Anderson EJ, Courtney DM et al: Community-Acquired Pneumonia Requiring Hospitalization among U.S. Adults. N Engl J Med 2015, 373(5):415-427.

15. Muthuri SG, Venkatesan S, Myles PR, Leonardi-Bee J, Lim WS, Al Mamun A, Anovadiya AP, Araujo WN, Azziz-Baumgartner E, Baez C et al: Impact of neuraminidase inhibitors on influenza $\mathrm{A}(\mathrm{H} 1 \mathrm{~N} 1)$ pdm09-related pneumonia: an individual participant data meta-analysis. Influenza Other Respir Viruses 2016, 10(3):192-204.

16. Memoli MJ, Athota R, Reed S, Czajkowski L, Bristol T, Proudfoot K, Hagey R, Voell J, Fiorentino C, Ademposi A et al: The natural history of influenza infection in the severely immunocompromised vs nonimmunocompromised hosts. Clin Infect Dis 2014, 58(2):214-224.

17. Collins JP, Campbell AP, Openo K, Farley MM, Cummings CN, Hill M, Schaffner W, Lindegren ML, Thomas A, Billing L et al: Outcomes of Immunocompromised Adults Hospitalized With Laboratoryconfirmed Influenza in the United States, 2011-2015. Clin Infect Dis 2020, 70(10):2121-2130.

18. Peteranderl C, Herold S, Schmoldt C: Human Influenza Virus Infections. Semin Respir Crit Care Med 2016, 37(4):487-500.

19. Lai ST: Treatment of severe acute respiratory syndrome. Eur J Clin Microbiol Infect Dis 2005, 24(9):583-591.

20. Davidson S: Treating Influenza Infection, From Now and Into the Future. Front Immunol 2018, 9:1946.

21. Bellelli V, d'Ettorre G, Celani L, Borrazzo C, Ceccarelli G, Venditti M: Clinical significance of lymphocytopenia in patients hospitalized with pneumonia caused by influenza virus. Crit Care 2019, 23(1):330.

22. Perez-Padilla R, de la Rosa-Zamboni D, Ponce de Leon S, Hernandez M, Quinones-Falconi F, Bautista E, Ramirez-Venegas A, Rojas-Serrano J, Ormsby CE, Corrales A et al: Pneumonia and respiratory failure from swine-origin influenza A (H1N1) in Mexico. N Engl J Med 2009, 361(7):680-689.

23. Boonnak K, Vogel L, Feldmann F, Feldmann H, Legge KL, Subbarao K: Lymphopenia associated with highly virulent H5N1 virus infection due to plasmacytoid dendritic cell-mediated apoptosis of T cells. J Immunol 2014, 192(12):5906-5912.

24. Smith PK, Wang SZ, Dowling KD, Forsyth KD: Leucocyte populations in respiratory syncytial virusinduced bronchiolitis. J Paediatr Child Health 2001, 37(2):146-151.

25. Shi SJ, Li H, Liu M, Liu YM, Zhou F, Liu B, Qu JX, Cao B: Mortality prediction to hospitalized patients with influenza pneumonia: PO2 /FiO2 combined lymphocyte count is the answer. Clin Respir J 2017, 
11(3):352-360.

26. Guo L, Wei D, Zhang X, Wu Y, Li Q, Zhou M, Qu J: Clinical Features Predicting Mortality Risk in Patients With Viral Pneumonia: The MuLBSTA Score. Front Microbiol 2019, 10:2752.

27. Titanji K, Ofotokun I, Weitzmann MN: Immature/transitional B-cell expansion is associated with bone loss in HIV-infected individuals with severe CD4+ T-cell lymphopenia. AIDS 2020, 34(10):1475-1483.

28. Zidar DA, Al-Kindi SG, Liu Y, Krieger NI, Perzynski AT, Osnard M, Nmai C, Anthony DD, Lederman MM, Freeman ML et al: Association of Lymphopenia With Risk of Mortality Among Adults in the US General Population. JAMA Netw Open 2019, 2(12):e1916526.

29. Choi SM, Boudreault AA, Xie H, Englund JA, Corey L, Boeckh M: Differences in clinical outcomes after 2009 influenza A/H1N1 and seasonal influenza among hematopoietic cell transplant recipients. Blood 2011, 117(19):5050-5056.

30. Lopez-Aldeguer J, Iribarren JA, Valencia E, Barquilla E, Knobel H, Santos J, Lozano F, Group GS: Outcomes in HIV-infected patients admitted due to pandemic influenza. Enferm Infecc Microbiol Clin 2012, 30(10):608-612.

31. Chertow DS, Memoli MJ: Bacterial coinfection in influenza: a grand rounds review. JAMA 2013, 309(3):275-282.

32. Cantan B, Luyt CE, Martin-Loeches I: Influenza Infections and Emergent Viral Infections in Intensive Care Unit. Semin Respir Crit Care Med 2019, 40(4):488-497.

33. Zou Q, Zheng S, Wang X, Liu S, Bao J, Yu F, Wu W, Wang X, Shen B, Zhou T et al: Influenza Aassociated severe pneumonia in hospitalized patients: Risk factors and NAl treatments. Int $\mathrm{J}$ Infect Dis 2020, 92:208-213.

34. Lee N, Hurt AC: Neuraminidase inhibitor resistance in influenza: a clinical perspective. Curr Opin Infect Dis 2018, 31(6):520-526.

35. Alonso M, Rodriguez-Sanchez B, Giannella M, Catalan P, Gayoso J, Lopez Bernaldo de Quiros JC, Bouza E, Garcia de Viedma D: Resistance and virulence mutations in patients with persistent infection by pandemic 2009 A/H1N1 influenza. J Clin Virol 2011, 50(2):114-118.

36. Hui DS, Lee N, Chan PK, Beigel JH: The role of adjuvant immunomodulatory agents for treatment of severe influenza. Antiviral Res 2018, 150:202-216.

\section{Tables}

Table 1 The clinical characteristics and outcomes of IC and non-IC patients with Flu-p 


\begin{tabular}{|c|c|c|c|c|}
\hline Variable & $\begin{array}{l}\text { Total } \\
(n=1313)\end{array}$ & $\begin{array}{l}\text { IC } \\
(n=122)\end{array}$ & $\begin{array}{l}\text { Non IC } \\
(n=1191)\end{array}$ & $\begin{array}{l}P \\
\text { value }\end{array}$ \\
\hline Age (yrs, median, IQR) & )$^{59.0(45.0-76.0}$ & $\begin{array}{l}45.0(32.8- \\
55.3)\end{array}$ & $61.0(49.0-78.0)$ & $\hat{L}_{0.001}$ \\
\hline Male $(n, \%)$ & $710(54.1)$ & $61(50.0)$ & $649(54.5)$ & 0.343 \\
\hline Influenza A infection $(n, \%)$ & $459(35.0)$ & $35(28.7)$ & $424(35.6)$ & 0.127 \\
\hline $\begin{array}{l}\text { Days from illness onset to admission } \\
\text { (median, IQR) }\end{array}$ & $3.0(2.0-5.0)$ & $\begin{array}{l}2.0(1.0- \\
3.0)\end{array}$ & $4.0(2.0-5.0)$ & $\hat{0.001}$ \\
\hline \multicolumn{5}{|l|}{ Comorbidities $(n, \%)$} \\
\hline Cardiovascular disease & $309(23.5)$ & $22(18.0)$ & $287(24.1)$ & 0.133 \\
\hline Diabetes mellitus & $162(12.3)$ & $14(11.5)$ & $148(12.4)$ & 0.761 \\
\hline Cerebrovascular disease & $128(9.7)$ & $14(11.5)$ & $114(9.6)$ & 0.500 \\
\hline COPD & $117(8.9)$ & 15 (12.3) & $102(8.6)$ & 0.168 \\
\hline Chronic kidney disease & $42(3.2)$ & $7(5.7)$ & $35(2.9)$ & 0.161 \\
\hline Asthma & $41(3.1)$ & $5(4.1)$ & $36(3.0)$ & 0.706 \\
\hline Obesity $(n, \%)$ & $86(6.5)$ & $5(4.1)$ & $81(6.8)$ & 0.250 \\
\hline Pregnancy $(n, \%)$ & $9(0.7)$ & $0(0.0)$ & $9(0.8)$ & 1.000 \\
\hline Smoking history $(n, \%)$ & $375(28.6)$ & $27(22.1)$ & $348(29.2)$ & 0.099 \\
\hline \multicolumn{5}{|l|}{$\begin{array}{l}\text { Baseline clinical and radiologic } \\
\text { features }(n, \%)\end{array}$} \\
\hline Fever $\geq 38^{\circ} \mathrm{C}$ & $990(75.4)$ & $78(63.9)$ & $912(76.6)$ & 0.002 \\
\hline Myalgia & $441(33.6)$ & $37(30.3)$ & $404(33.9)$ & 0.424 \\
\hline Sore throat & $235(17.9)$ & 19 (15.6) & $216(18.1)$ & 0.482 \\
\hline Cough & $1290(98.2)$ & $119(97.5)$ & $1171(98.3)$ & 0.532 \\
\hline Sputum & $1032(78.6)$ & $90(73.8)$ & $942(79.1)$ & 0.172 \\
\hline Chest pain & $243(18.5)$ & $38(31.1)$ & $205(17.2)$ & $\dot{0.001}$ \\
\hline Respiratory rates $\geq 30$ breaths $/ \mathrm{min}$ & $178(13.6)$ & 19 (15.6) & $159(13.4)$ & 0.494 \\
\hline Altered mental status & $179(13.6)$ & $12(9.8)$ & $167(14.0)$ & 0.199 \\
\hline $\mathrm{SBP}<90 \mathrm{mmHg}$ & $21(1.6)$ & $4(3.3)$ & $17(1.4)$ & 0.121 \\
\hline Leukocytes $\left(\times 10^{9} / \mathrm{L}\right)$ & $7.6 \pm 3.9$ & $7.4 \pm 4.2$ & $7.6 \pm 3.9$ & 0.647 \\
\hline
\end{tabular}




\begin{tabular}{|c|c|c|c|c|}
\hline Lymphocytes $\left(\times 10^{9} / \mathrm{L}\right)$ & $\begin{array}{l}1.1 \pm 0.8, n= \\
1211\end{array}$ & $0.9 \pm 0.6$ & $\begin{array}{l}1.2 \pm 0.8, n \\
=1089\end{array}$ & $\begin{array}{l}<.001 \\
0.01\end{array}$ \\
\hline $\mathrm{HB}(\mathrm{g} / \mathrm{L})$ & $123.1 \pm 23.0$ & $\begin{array}{l}122.9 \pm \\
23.2\end{array}$ & $123.1 \pm 23.0$ & 0.907 \\
\hline ALB (g/L) & $\begin{array}{l}28.7 \pm 5.4, n= \\
1169\end{array}$ & $28.4 \pm 6.0$ & $\begin{array}{l}28.8 \pm 5.3, n= \\
1047\end{array}$ & 0.451 \\
\hline BUN (mmol/L) & $\begin{array}{l}6.8 \pm 4.1, n= \\
1221\end{array}$ & $6.3 \pm 3.7$ & $\begin{array}{l}6.8 \pm 4.1, n= \\
1099\end{array}$ & 0.214 \\
\hline $\mathrm{PaO}_{2} / \mathrm{FiO}_{2}(\mathrm{mmHg})$ & $\begin{array}{l}319.7 \pm 116.8, n \\
=1170\end{array}$ & $\begin{array}{l}312.6 \pm \\
71.9\end{array}$ & $\begin{array}{l}320.8 \pm 121.8, n \\
=1048\end{array}$ & 0.468 \\
\hline Multilobar infiltrates & $958(73.0)$ & $85(69.7)$ & $873(73.3)$ & 0.390 \\
\hline Pleural effusion & 439 (33.4) & $58(47.5)$ & $381(32.0)$ & 0.001 \\
\hline Coinfection $(n, \%)$ & $458(34.9)$ & $53(43.4)$ & $405(34.0)$ & 0.037 \\
\hline \multicolumn{5}{|l|}{ Clinical treatment and outcomes } \\
\hline Early NAI therapy $(n, \%)$ & 495 (37.7) & $55(45.1)$ & $437(36.7)$ & 0.068 \\
\hline $\begin{array}{l}\text { Systemic corticosteroids use at } \\
\text { admission }(n, \%)\end{array}$ & $116(8.8)$ & $32(26.2)$ & $84(7.1)$ & $<.001$ \\
\hline Noninvasive ventilation $(n, \%)$ & $365(27.8)$ & $59(48.4)$ & $306(25.7)$ & $\begin{array}{l}<.001 \\
0.00\end{array}$ \\
\hline Invasive ventilation $(n, \%)$ & $248(18.9)$ & $37(30.3)$ & $211(17.7)$ & 0.001 \\
\hline \multicolumn{5}{|c|}{$\begin{array}{l}\text { Complications during hospitalization } \\
(n, \%)\end{array}$} \\
\hline Respiratory failure & $323(24.6)$ & $50(41.0)$ & $273(22.9)$ & $\begin{array}{l}<.001 \\
0.001\end{array}$ \\
\hline Heart failure & 327 (24.9) & $42(34.4)$ & 285 (23.9) & 0.011 \\
\hline Nosocomial pneumonia & $109(8.3)$ & $21(17.2)$ & $88(7.4)$ & $\begin{array}{l}<.001 \\
0.001\end{array}$ \\
\hline Septic shock & $119(9.1)$ & $24(19.7)$ & $95(8.0)$ & $\begin{array}{l}<.001 \\
0.001\end{array}$ \\
\hline Nosocomial BSI & $18(1.4)$ & $9(7.4)$ & $9(0.8)$ & $\begin{array}{l}< \\
0.001\end{array}$ \\
\hline Acute renal failure & $79(0.6)$ & $8(6.6)$ & $71(6.0)$ & 0.592 \\
\hline Admittance to ICU $(n, \%)$ & $326(24.8)$ & $59(48.4)$ & $267(22.4)$ & <.001 \\
\hline $\begin{array}{l}\text { Days from clinical stability to } \\
\text { admission (median, IQR) }\end{array}$ & $3.0(1.0-9.0)$ & $\begin{array}{l}14.0(10.0- \\
19.0)\end{array}$ & $3.0(1.0-8.0)$ & $<.001$ \\
\hline
\end{tabular}


Length of stay in hospital

(days, median, IQR)

30-day mortality $(n, \%)$
$10.0(8.0-17.0)$

$315(24.0)$ $17.0(11.0-\quad 10.0(8.0-14.0)$ 22.0)
$<$ 0.001

$46(37.7) \quad 242(20.3)$

<.001

IC: immunocompromised; IQR: interquartile range; COPD: chronic obstructive pulmonary disease; SBP: systolic blood pressure; $\mathrm{HB}$ : hemoglobin; ALB: albumin; $\mathrm{BUN}$ : blood urea nitrogen; $\mathrm{PaO}_{2} / \mathrm{FiO}_{2}$ : arterial pressure of oxygen/fraction of inspiration oxygen; NAl: neuraminidase inhibitor; BSI: bloodstream infection; ICU: The bolded values are p-values $<0.05$, which represented significant differences between IC and non-IC patients with Flu-p. The bolded values are $p$-values $<0.05$, which represented significant differences between IC and non-IC patients.

Table 2 The impact of immuncompromised status on the clinical outcomes of Flu-p patients

\begin{tabular}{|lllll|}
\hline Clinical outcomes & \multicolumn{2}{l}{ Univariate logistic analysis } & \multicolumn{2}{l|}{ Multivariate logistic analysis } \\
\cline { 2 - 6 } & OR(95\% CI) & $\boldsymbol{P}$ value & OR $(95 \%$ CI & $\boldsymbol{P}$ value \\
\hline Invasive ventilation & $2.022(1.337-3.058)$ & 0.001 & $2.475(1.511-4.053)$ & $<0.001$ \\
\hline ICU admission & $3.241(2.216-4.741)$ & $<0.001$ & $3.247(2.064-5.106)$ & $<0.001$ \\
\hline 30-day mortality & $2.374(1.603-3.514)$ & $<0.001$ & $3.206(1.926-5.335)$ & $<0.001$ \\
\hline
\end{tabular}

OR: odd ratio; Cl: confidence interval.

Table 3 Risk factors for mortality in IC patients with Flu-p

\begin{tabular}{|lll|}
\hline Variable & OR $(95 \%$ Cl & $P$ value \\
\hline Lymphocyte counts & $0.993(0.990-0.996)$ & $<0.001$ \\
\hline Coinfection & $5.450(1.638-18.167)$ & 0.006 \\
\hline Early NAl therapy & $0.401(0.127-0.878)$ & 0.001 \\
\hline Systemic corticosteroids use & $6.414(1.348-30.512)$ & 0.020 \\
\hline
\end{tabular}

\section{Figures}




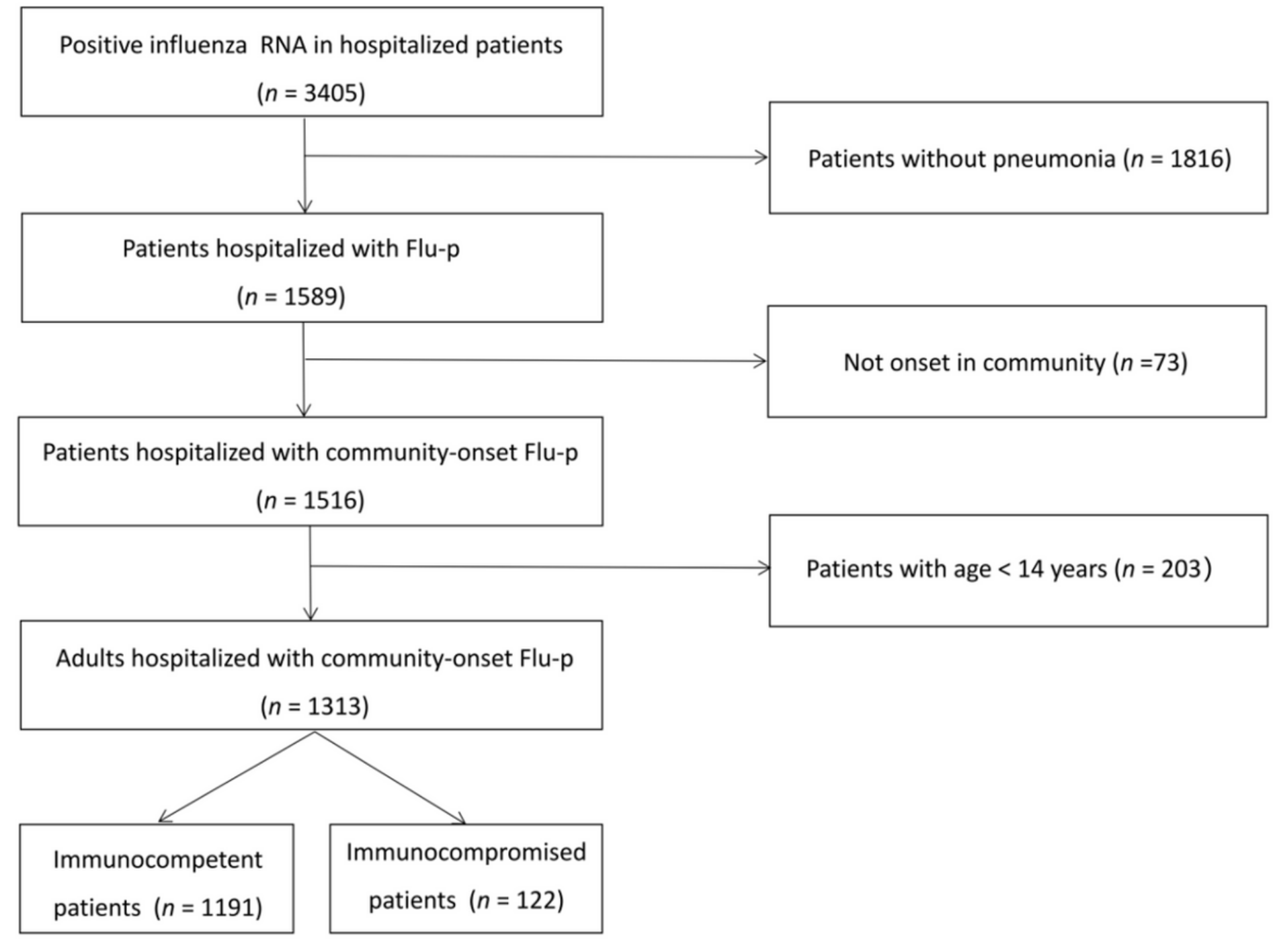

\section{Figure 1}

Screening algorithm of patients hospitalized with Flu-p. A total of 3405 hospitalized patients with RNA tests positive for influenza and 1313 eligible adult patients with Flu-p were included in the final analysis. 


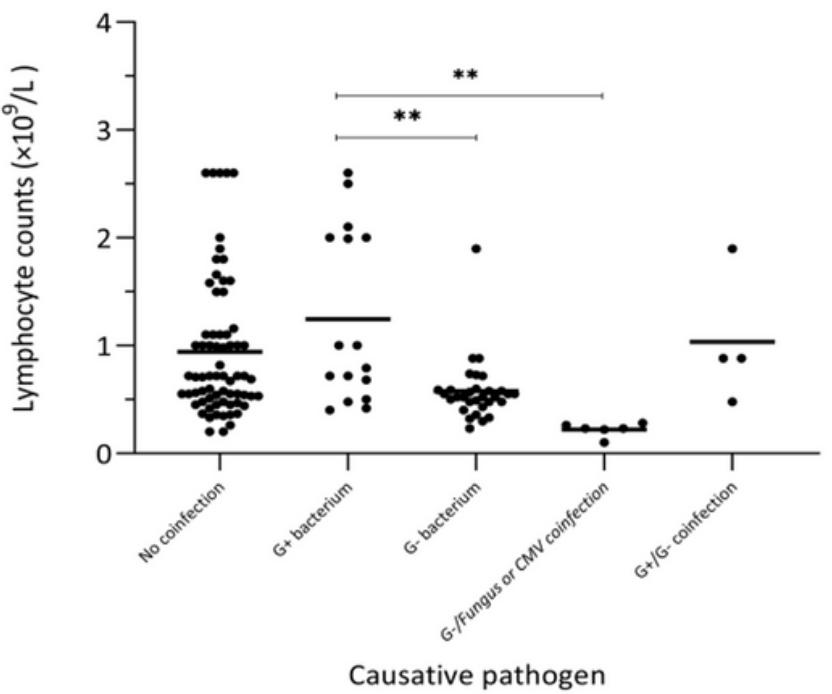

(A)

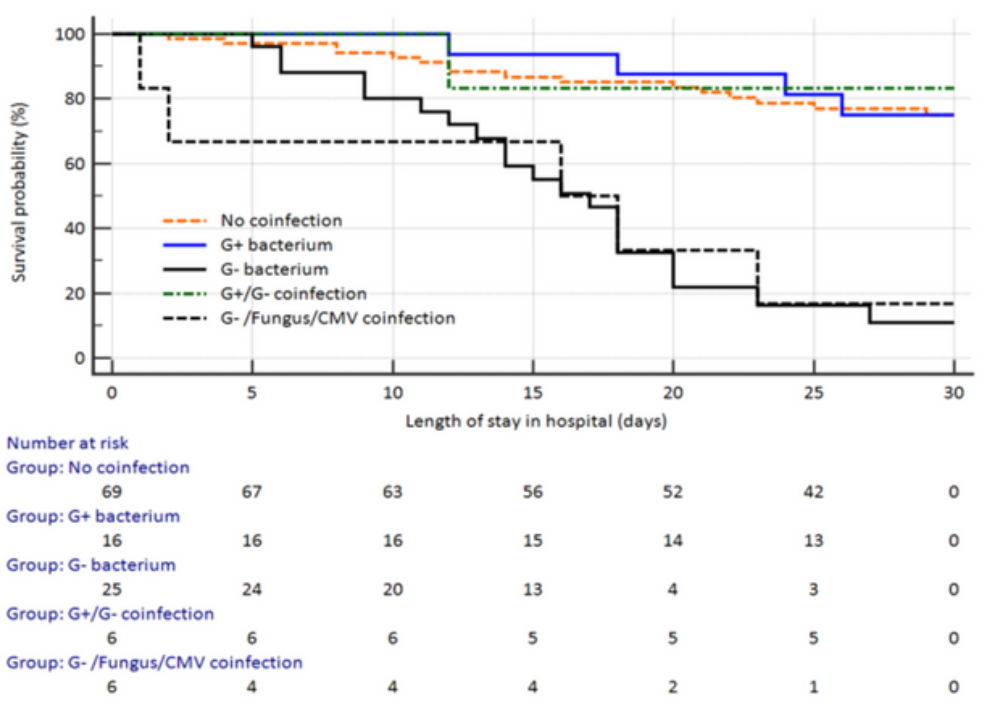

(B)

\section{Figure 2}

(A) Comparison of lymphocyte counts of patients with different causative pathogens; (B) Kaplan-Meier curves showing the survival probabilities of patients with different causative pathogens. $(* \star$ : $p<0.001)$. A The baseline lymphocyte count levels for IC patients coinfected with gram-positive bacteriumwas significantly higher than those for IC patients coinfected with gram-negative bacterium, gram-negative bacterium/fungus or CMV; B The survival rates of IC patients coinfected with gram-negative bacteriumand gram-negative bacterium/fungus or CMV were lower than those of IC patients coinfected with gram-positive bacterium during the first 30 days after admission.

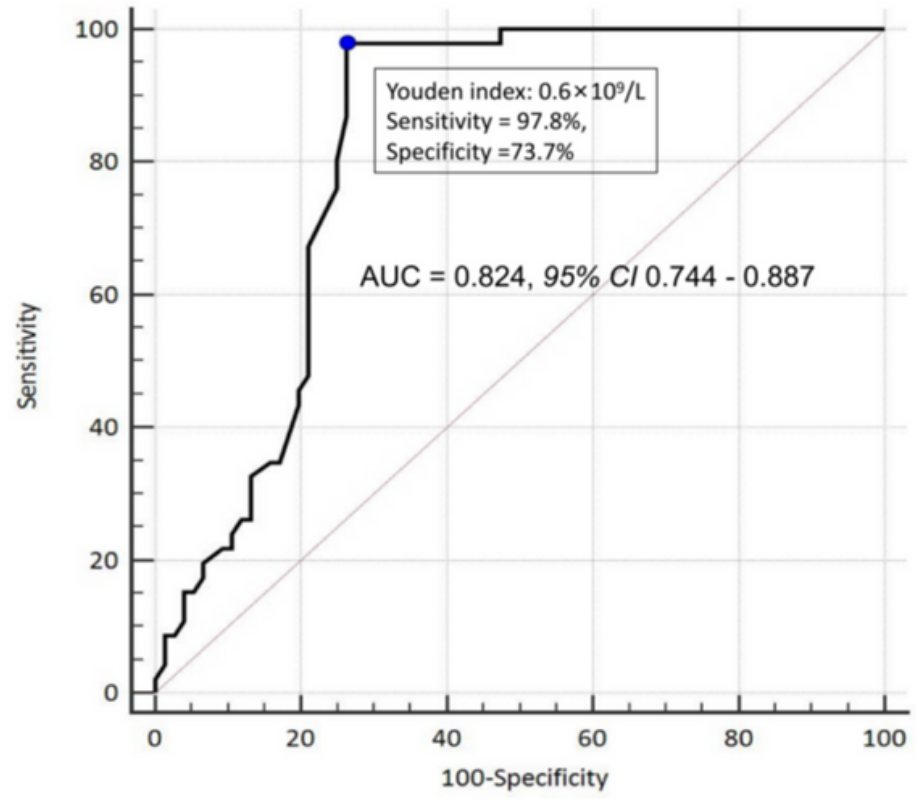

(A)

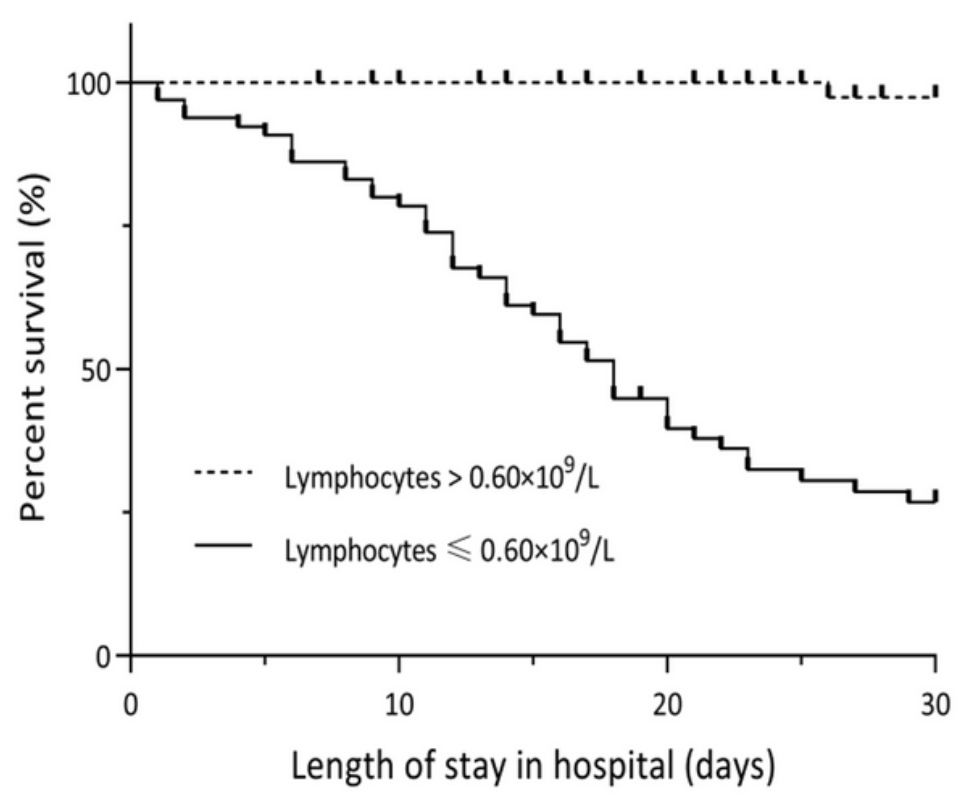

(B) 


\section{Figure 3}

3 (A) ROCs for mortality prediction of lymphocytes among IC patients with Flu-p; (B) Kaplan-Meier curves showing the survival probabilities of patients with two levels of lymphocyte counts. A The ROC determined that the optimal cutoff of baseline lymphocyte counts was $0.6 \times 109 / \mathrm{L}$, which reached an AUROC of 0.825 ( $95 \% \mathrm{Cl}$ : $0.744-0.887)$, with sensitivity of $97.8 \%$ and specificity of $73.7 \%$; B The KaplanMeier curves showed that the 30-day mortality of IC patients with baseline lymphocyte counts $\leq$ $0.6 \times 109 / \mathrm{L}$ was higher than that of patients with lymphocyte counts $>0.6 \times 109 / \mathrm{L}$.

\section{Supplementary Files}

This is a list of supplementary files associated with this preprint. Click to download.

- SupplementaryMaterial1.docx 